\title{
Hospital Brand Image, Service Quality, and Patient Satisfaction in Pandemic Situation
}

\section{Tjokorda Gde Raka Sukawati}

Correspondence Author: tjokde@unud.ac.id

Management Department. Faculty of economics and business Udayana University. Bali, Indonesia

\section{N D E X I N G}

Keywords:

Hospital Brand

Image;

Service Quality;

Patient Satisfaction;

Kata kunci:

Citra Merek Rumah

Sakit;

Kualitas Layanan;

Kepuasan Pasien;

\begin{abstract}
A B S T R AC T
The aim of this research was to analyze the effect of hospital brand image, service quality and patient satisfaction on hospital service user in Denpasar, Bali. This study was conducted during the current pandemic. This study aimed at testing the important mediation role of service quality in relation to hospital brand image on patient satisfaction. This study took the research samples of 81 respondents who used medical services at hospitals in Denpasar. The simple random sampling technique was used to collect the data. The hypothesis test results show that hospital brand image positively, significantly influences patient satisfaction. Hospital brand image positively, significantly influences service quality. Service quality positively, significantly influences patient satisfaction.
\end{abstract}

C 2021 JMMR. All rights reserved

Article history: Received 2021-06-05; Revised 2021-07-05; Accepted 2021-07-24

\section{INTRODUCTION}

Research on customer behavior is still an interesting topic of study, thus it is necessary to study it more thoroughly in line with the development of pattern and interaction of customer with brand (Park, MacInnis, \& Priester, 2006). Consumer behavior covers consumer's activities before purchase, during purchase process and after purchase and company's exploration of potential customer. One of the topics studied in learning consumer behavior is the relationship of service quality with brand image (Papista \& Dimitriadis, 2012).

Brand image affects customer decision (Wu, 2011a). Brand image inherent in consumer is a continuous process created by organization and a creation of value for customer (Rajagopal, 2007). The digital era, as marked with good technology utilization, and the availability of services easily accessed by customer make service provider gives superior services. The effort carried out by company in building good brand image includes through understanding the types of company's customers (Tanford, Raab, \& Kim, 2011). Good brand image also encourages organization to create service quality. The study conducted by Hess and Story (2005) states that customer will have satisfaction higher than what company expects if the organization provides better services. 
The study conducted by Sahin, Zehir, and Kitapçı (2011) shows the results that brand trust, brand experience and satisfaction affect brand loyalty. Meanwhile, Eric Aysel, Sevtap, Candan, and Hatice (2012) in their study find that brand satisfaction and brand trust affect the commitment and desire to repurchase a product, thus it affects loyalty. Patient satisfaction becomes service company's focus in developing its business (Abekah-Nkrumah, Yaa Antwi, Braimah, \& Ofori, 2020).

This study focuses on health services. Patient satisfaction is the variable tested in this study with hospital brand image and hospital service quality as the antecedents. This study also empirically proves the effect of hospital brand image on service quality and patient satisfaction. The test on important mediation role of hospital service quality in empirically proving the relationship of hospital brand image with patient satisfaction is also empirically proven in this study.

Brand is a valuable intangible asset that is difficult to imitat, and helps organization achieve excellent continuous performance (Roberts \& Dowling, 2002). Brand image is a combination of quality felt and dimensions of brand. Brand image is also perception of brand retained by customer's memory that reflects customer's whole impression. Positive brand image is an important part of company's capability of maintaining its market position. This study measures the brand image of hospital. Hospital brand image is the accumulation of patient' belief, ideas, and impression of the services given by hospital. The brand inherent in hospital is also determined by medical examination process and treatment experience (Kim, Kim, Kim, Kim, \& Kang, 2008). Furthermore, hospital brand image has strategic function. Through marketing strategy, brand image inherent in hospital can be used to help improve organization's relative position (Wu, 2011a). Therefore, beneficial hospital brand image helps strengthen patient's intention to choose hospital.

Brand image affects customer satisfaction. Satisfaction is customer response to fulfillment of their needs. Satisfaction is the assessment of products or services that successfully satisfy their needs at satisfactory level, either below or above expectation (Oliver, 1999). The affective experience approach views that satisfaction level is influenced by positive and negative feeling that customer associates with certain service after it has been chosen by the customer (Hasan, 2008). It is further explained that satisfaction is an affective response to buy a situation. Satisfaction is also a positive affective reaction for the result of previous experience, since satisfaction is derived from the attitude formed partially from previous experience. Based on previous theoretical studies and research, the following hypothesis can be developed.

H1: Hospital brand image positively, significantly influences patient satisfaction.

Service quality is closely related to service attitude and decision in fulfilling customer's expectation (Guo \& Wang, 2015). Service quality is also organization's choice of decision that is related to service superiority. The concept of service quality is viewed as the level and direction of compatibility between consumer's perception and expectation. Customer forms expectation before they obtain service that they will choose. Consumer develops perception during service delivery process, and compares the perception with the expectation that will be received, and then evaluates the result of the service (Wu, 2011b). Tan, Wong, Lam, Ooi, and $\mathrm{Ng}$ (2010) define service quality as a process of service delivery that must meet customer's 
requirements and expectation. In this perspective, service quality can be viewed as the measure of how good the level of service delivered according to customer's expectation.

Kotler and Keller (2012) explain that service quality must start with customer's needs and end with customer's perception. The concept of service quality is closely related to good service quality given by organization. Good service quality is not viewed from service provider's perception, but based on customer's perception. Customer's perception of service quality is a thorough assessment of the superiority of service provided by organization to customer. This study tests the concept of service quality given by hospital. The context of service quality given by hospital in this case is health care service. The study conducted by Woodside, Frey, and Daly (1989) explains hospital service quality as the gap between the expectation of and perception received by patient. Expectation is treated when patient thinks of what is offered by hospital, such as medical service. Perception can be viewed as evaluation of medical service for patient and relative attribute of the expectation received by patient. Hospital service quality depends on the balance between patient's perception and expectation. Based on previous theoretical studies and research, the following hypothesis can be developed.

H2: Hospital brand image positively, significantly influences hospital service quality.

Satisfaction is the focus of organization's strategy in maintaining customers. Satisfaction can be achieved through, among others, customer trust, so that it will lead to loyalty to the product or service chosen. If organization gives better satisfaction than what customer expects, trust will be created in service quality felt by customers. The study conducted by Sahin et al. (2011) shows the results that customer satisfaction affects loyalty. Meanwhile, Eric Aysel et al. (2012) explains that satisfaction can affect customer's commitment and desire to repurchase a product. Customer satisfaction is the focus of organization in developing the choice of strategy for development in facing the change in quite strict competition. The study conducted by Padma, Rajendran, and Sai Lokachari (2010) explains that customer satisfaction is organization's strength, objective and driver in making strategy creativity, so as to lead to loyalty customer and excellent performance. Customer satisfaction can be examined when customer has used company's product or service.

This study tests the relationship between hospital service quality and patient satisfaction. In some previous researches, service quality is commonly called SERQUAL. Parasuraman (1998) explains five dimensions SERVQUAL consisting of, first, responsiveness, that is organization's capability to quickly and appropriately respond to customer. Second, tangibles, that is organization's capability to prepare physical facilities and infrastructure to serve customer. Third, reliability, that is organization's capability to provide reliable service to customers. Fourth, assurance, that is assurance from organization in delivering knowledge, and employees' capability to create customer trust in organization. Fifth, empathy, that is organization's concern about customer, understanding of customer's needs and the convenience of customers of service provided by organization.

Some other researchers study the relationship of service quality with satisfaction. The research results find that high service quality is strongly correlated with customer satisfaction, such as that in the study conducted by (George \& Kumar, 2014; Rashid, Rani, Yusuf, \& 
Shaari, 2015; Sanyal \& Hisam, 2016). This study tests service quality and satisfaction in health service sector, particularly the relationship between service quality and patient satisfaction. Woodside et al. (1989) in their study find that patient satisfaction serves to intervene service quality and behavioral intention. Meanwhile, Anderson and Sullivan (1993) find satisfaction as a certain factor in determining loyalty customer. Meanwhile Sanyal and Hisam (2016) proves that there is a close relationship between service quality and customer satisfaction. Based on the literature review and previous researches and study, the following hypothesis can be developed.

H3: Hospital service quality positively, significantly influences patient satisfaction.

Based on figure 1. previous study and literature review, the empirical research model can be developed

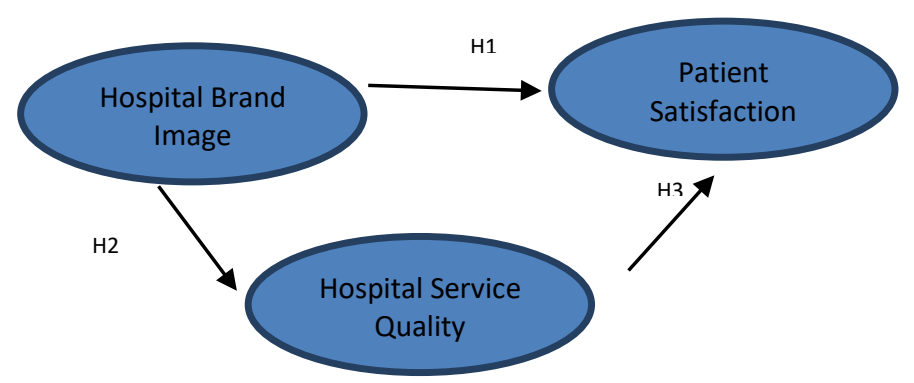

Figure 1. The Empirical Research Model

\section{RESEARCH METHOD}

This study used quantitative approach, that is used to test the causality of relationship between research variables and measure the concept and as the base of hypothesis making. The data collection technique used was survey. The instrument used in the survey was questionnaire. This study was conducted on the patients of hospitals in Denpasar, Bali. The samples in this study were taken through survey using link on Google Form with out-patients of public hospitals in Denpasar Bali. The number of samples studied was 81 patients, who were sampled using simple random sampling. Hospital brand image, according to Kim et al. (2008), is the accumulation of patient's belief, ide, and impression of services provided by hospital. The hospital brand image was measured in this study using Likert scale $1-5$.

Scale 1 shows strongly disagreeing response, and scale 5 shows strongly agreeing response. The indicators in measuring hospital brand image in this study were, among others: hospital's good reputation, superiority of hospital's facilities, hospital's convenient environment, and hospital's excellent service. Service quality is the difference obtained from comparing the expectation of and the reality received by patient (Zeithaml, Parasuraman, \& Malhotra, 2001). Hospital service quality in this study was measured using five dimensions reflected in the indicators of each dimension. The five indicators were measured using Likert scale $1-5$. Scale 1 shows strongly disagreeing response, and scale 5 shows strongly agreeing response. The five indicators of hospital service quality are, among others: availability of sufficient physical facilities and equipment, speed of service provision for patient, reliability 
of medical workers and doctors, hospitality of service provided by medical workers and good care for patient.

Satisfaction is the level of feeling in which a person states the result of comparison between the performance received and his expectation (Kotler \& Keller, 2012). Patient satisfaction in this study was measured using Likert scale $1-5$. The indicators of patient satisfaction in this research are, among others: satisfaction of nurse service, satisfaction of the use of medical instruments, satisfaction of administrative service, and desire to reuse hospital's service..

\section{Validity and Reliability Tests}

\section{RESULT AND DISCUSSION}

This study tests the research hypotheses using SPSS program. The initial test was carried out by viewing validity and reliability tests. SPSS program was used to test the hypotheses using path analysis. The first test was instrument test, carried out to view the validity and reliability of an instrument. The result of validity and reliability tests on the instruments was examined using SPSS by viewing the loading factor value on the rotated component matrix of each instrument. The results of validity test show that each instrument has loading factor value $>0.6$, thus we may conclude that the instruments were statistically valid. Meanwhile, the reliability test shows that the Cronbach alpha value of each variable shows $>0.6$, thus we may conclude that each variable was statistically reliable. The results of validity and reliability tests on the hospital brand image, hospital service quality and patient satisfaction variable are explained in table 1 below.

Table 1. Result of validity and reliability test

\begin{tabular}{|c|c|c|c|c|}
\hline & \multicolumn{3}{|c|}{ Component } & \multirow[t]{2}{*}{ Cronbach alpha } \\
\hline & 1 & 2 & 3 & \\
\hline image1 & & & 0.814 & \multirow{4}{*}{0.848} \\
\hline image2 & & & 0.795 & \\
\hline image3 & & & 0.755 & \\
\hline image4 & & & 0.749 & \\
\hline servqual1 & 0.601 & & & \multirow{5}{*}{0.887} \\
\hline servqual2 & 0.875 & & & \\
\hline servqual3 & 0.895 & & & \\
\hline servqual4 & 0.885 & & & \\
\hline servqual5 & 0.877 & & & \\
\hline satis1 & \multicolumn{3}{|c|}{0.769} & \multirow{4}{*}{0.880} \\
\hline satis2 & \multicolumn{3}{|c|}{0.865} & \\
\hline satis3 & & 0.848 & & \\
\hline$\overline{\text { satis4 }}$ & & 0.828 & & \\
\hline
\end{tabular}




\section{Hypothesis Test Result}

The empirical test on hypothesis 1 through hypothesis 3 in this study was conducted using path analysis. Path analysis tests the role of mediation regression, as explained in table 2 , table 3, and table 4 . The results of test on hypothesis 1 through hypothesis 3 are explained below.

Table 2. Regression for hospital brand image on patient satisfaction

\begin{tabular}{lccccc}
\hline $\begin{array}{l}\text { Hospital brand image and patient } \\
\text { satisfactien }\end{array}$ & $\begin{array}{c}\text { Predictor } \\
\text { Variables }\end{array}$ & $\boldsymbol{\beta}$ unstd. & $\boldsymbol{\beta}$ std. & $\mathbf{t}$ & Sig \\
\hline $\begin{array}{l}\text { Dependent variable : Patient satisfaction } \\
\text { Adj. R } \mathrm{R}^{2} 0.328-\operatorname{sig} 0.000\end{array}$ & $\begin{array}{c}\text { Hospital brand } \\
\text { image }\end{array}$ & 0.549 & 0.580 & 6.331 & 0.000 \\
\hline
\end{tabular}

Table 3. Regression for hospital brand image on hospital service quality

\begin{tabular}{lccccc}
\hline $\begin{array}{l}\text { Hospital brand image and hospital service } \\
\text { quality }\end{array}$ & $\begin{array}{c}\text { Predictor Variables } \\
\boldsymbol{\beta} \text { unstd. }\end{array}$ & $\boldsymbol{\beta}$ std. & $\mathrm{t}$ & Sig \\
\hline $\begin{array}{l}\text { Dependent variable : hospital service quality } \\
\text { Adj. } \mathrm{R}^{2} 0.489 \text { - sig } 0.000\end{array}$ & $\begin{array}{c}\text { Hospital brand } \\
\text { image }\end{array}$ & 0.876 & 0.704 & 8.810 & 0.000 \\
\hline
\end{tabular}

Table 4. Mediating Regression for hospital brand image, hospital service quality on patient satisfaction

\begin{tabular}{lccc}
\multicolumn{1}{c}{ Path analysis } & $\boldsymbol{\beta}$ & $\boldsymbol{\beta}$ std. & Result \\
\hline $\begin{array}{l}\text { Unstd. } \\
\text { service quality }\end{array}$ & 0.876 & 0.704 & H1 supported \\
$\begin{array}{l}\text { Hospital brand image - patient } \\
\text { satisfaction }\end{array}$ & 0.549 & 0.580 & H2 supported \\
\hline $\begin{array}{l}\text { Path analysis } \\
\begin{array}{l}\text { Hospital brand image - Hospital } \\
\text { service quality - patient satisfaction }\end{array}\end{array}$ & $0.704 \times 0.580=0.408$ & H3 supported \\
\hline
\end{tabular}

The result of $\mathrm{H} 1$ test on the influence of hospital brand image on patient satisfaction is shown in Table 2. Table 2 shows the result of regression coefficient value of the influence of hospital brand image on patient satisfaction of $0.580(t=6.331>1.96)$ with significance value $(0.000<0.05)$. The test on $\mathrm{H} 1$ indicates that hospital brand image positively, significantly influences patient satisfaction. Hypothesis 1 is accepted. The result of $\mathrm{H} 2$ test on the influence of hospital brand image on hospital service quality shows the result of regression coefficient value of $0.704(t=8.810>1.96)$ with significance value $(0.000<0.05)$. The result of $\mathrm{H} 2$ test indicates that hospital brand image positively, significantly influences hospital service quality. Hypothesis 2 is accepted.

The result of $\mathrm{H} 3$ test on the influence of hospital brand image on patient satisfaction with hospital service quality as mediation shows the result of regression coefficient value of 0.408. The result of $\mathrm{H} 3$ test indicates that hospital service quality positively, significantly mediates the relationship of hospital brand image with patient satisfaction. Hypothesis 3 is accepted. 


\section{Discussion}

This research result supports the finding of previous study that brand is determined by service provided by medical workers (Kim et al., 2008). Furthermore, the finding of this study is also in line with previous finding stating that hospital has strategic function through its ability to build brand image in improving organization's relative position (Wu, 2011a). The test on other hypothesis finds that hospital brand image positively, significantly influences service quality. This research finding supports previous study that service quality is closely related to customer's expectation (Guo \& Wang, 2015). This study result confirms previous study that consumer will develop their perception in the process of service delivery and then evaluate the result of service (Wu, 2011b).

The result of hypothesis test also finds that hospital service quality positively, significantly affects patient satisfaction. This study finding supports previous study conducted by Woodside et al. (1989) that patient satisfaction intervenes service quality and behavioral intention. This study also supports the result of research conducted by Anderson and Sullivan (1993) that satisfaction is the determinant factor in determining customer loyalty. The study conducted by Sanyal and Hisam (2016) is also in line with the result of this study that there is a close relationship between service quality and customer satisfaction.

The results of this study indicates that it is necessary to improve hospital brand image through improving hospital's good reputation, improving hospital's excellent facilities and provision of hospital's convenient environment. Theoretically, this proves the dimensions of SERVQUAL developed by (Parasuraman, 1998). The dimensions are, among others, tangibles, reliability, responsiveness, emphatic and assurance. The results of this study recommend development of more comprehensive empirical research model, the concept of brand image, service quality and satisfaction so that later it can be tested in different scope of samples, considering that this study was conducted during the current Covid-19 Pandemic. It is also necessary to consider the limitation of the number of samples and sampling technique of the research.

\section{CONCLUSION}

This study empirically proves the influence of hospital brand image on service quality and patient satisfaction. In addition, this study also tests the role of important mediation of hospital service quality in proving empirically the relationship of hospital brand image with patient satisfaction. This research gives an important contribution to testing the influence of hospital brand image on service quality and patient satisfaction. The results of this study also have practical and theoretical implications. Practically, the results of this study recommend hospital management to continuously improve their image through provision of good services, so that patient satisfaction will be maintained. The results of this study also recommend that hospital brand image directly and indirectly improves patient satisfaction.

\section{REFERENCE}

Abekah-Nkrumah, G., Yaa Antwi, M., Braimah, S. M., \& Ofori, C. G. (2020). Customer relationship management and patient satisfaction and loyalty in selected hospitals in Ghana. International Journal of Pharmaceutical and Healthcare Marketing, ahead-ofprint(ahead-of-print). doi: 10.1108/ijphm-09-2019-0064 
Anderson, E. W., \& Sullivan, M. W. (1993). The Antecedents and Consequences of Customer Satisfaction For Firms. Marketing Science, Vol. 12. 2., pg. 125.

Eric Aysel, Sevtap, U., Candan, B. F., \& Hatice, Y. (2012). The effect of brand satisfaction, trust and brand commitment on

loyalty and repurchase intentions. Procedia - Social and Behavioral Sciences, 58, 1395 - 1404.

George, A., \& Kumar, G. S. G. (2014). Impact of service quality dimensions in internet banking on customer satisfaction. Decision, 41(1), 73-85. doi: 10.1007/s40622-0140028-2

Guo, C., \& Wang, Y. (2015). How manufacturer market orientation influences B2B customer satisfaction and retention: empirical investigation of the three market orientation components. Journal of Business $\mathcal{E}$ Industrial Marketing, 30(2), 182-193. doi: 10.1108/jbim-03-2012-0042

Hasan, A. (2008). Marketing. Yogyakarta: MedPress.

Hess, J., \& Story, J. (2005). Trust-based commitment: multidimensional

consumer-brand relationships. Journal of Consumer Marketing, 22(6), 313-322.

Kim, K. H., Kim, K. S., Kim, D. Y., Kim, J. H., \& Kang, S. H. (2008). Brand equity in hospital marketing. Journal of Business Research, 1(61), 75-82.

Kotler, P., \& Keller, K. (2012). Marketing Management (14th Edition).

Oliver, R. L. (1999). Whence consumer loyalty? Journal of Marketing, 63(special Issue), 33-44.

Padma, P., Rajendran, C., \& Sai Lokachari, P. (2010). Service quality and its impact on customer satisfaction in Indian hospitals. Benchmarking: An International Journal, 17(6), 807-841. doi: 10.1108/14635771011089746

Papista, E., \& Dimitriadis, S. (2012). Exploring consumer-brand relationship quality and identification. Qualitative Market Research: An International Journal, 15(1), 33-56. doi: $10.1108 / 13522751211191982$

Parasuraman, A. (1998). Customer service in business-to-business markets: an agenda for research. Journal of Business $\mathcal{E}$ Industrial Marketing, 13(4/5), 309-321.

Park, C. W., MacInnis, D. J., \& Priester, J. (2006). Beyond attitudes: Attachment and consumer behavior. Seoul Journal of Business, 12.

Rajagopal. (2007). Buying decisions towards organic products: an analysis of customer value and brand drivers. International Journal of Emerging Markets, 2(3), 236-251. doi: $10.1108 / 17468800710758387$

Rashid, I. M. A., Rani, M. J. A., Yusuf, B. N. M., \& Shaari, M. S. (2015). The Impact of Service Quality and Customer Satisfaction on Customer's Loyalty: Evidence From Fast Food Restaurant of Malaysia. International Journal of Information, Business and Management, 7(4), 201. 
Roberts, P. W., \& Dowling, G. R. (2002). Corporate reputation and sustained superior financial performance. Strategic Management Journal, 23(12), 1077-1093.

Sahin, A., Zehir, C., \& Kitapçı, H. (2011). The Effects of Brand Experiences, Trust and Satisfaction on Building Brand Loyalty; An Empirical Research On Global Brands. Procedia Social and Behavioral Sciences, 24, 1288-1301.

Sanyal, S., \& Hisam, M. W. (2016). An Analysis of the Impact of Service Quality and Passenger Satisfaction on Passenger Preference for Airlines: A Study of the Indian Aviation Sector. International Review of Management and Marketing, 6(2).

Tan, B.-I., Wong, C.-H., Lam, C.-H., Ooi, K.-B., \& Ng, F. C.-Y. (2010). Assessing the link between service quality dimensions and knowledge sharing: Student perspective. African Journal of Business Management, 4(6), 1014-1022.

Tanford, S., Raab, C., \& Kim, Y.-S. (2011). The Influence of Reward Program Membership and Commitment on Hotel Loyalty. Journal of Hospitality $\mathcal{E}$ Tourism Research, 35(3), 279 . 307.

Woodside, A. G., Frey, L. L., \& Daly, R. T. (1989). Linking Service Quality, Customer Satisfaction, And Behavio. Marketing Health Services, 9(4), 5.

Wu, C.-C. (2011a). The impact of hospital brand image on service quality, patient satisfaction and loyalty. African Journal of Business Management, 5(12), 4873-4882.

Wu, C.-C. (2011b). The impact of hospital brand image on service quality, patient satisfaction and loyalty. African Journal of Business Management, Vol. 5(12),, pp. 4873. 4882. doi: $10.5897 /$ ajbm 10.1347

Zeithaml, V. A., Parasuraman, A., \& Malhotra, A. (2001). "A conceptual framework for understanding e-service quality: implications for future research and managerial practice”, Working Paper, Report. Marketing Science Institute, Cambridge, MA, No. 00-115. 